\title{
Gum Dosing Unit
}

National Cancer Institute

\section{Source}

National Cancer Institute. Gum Dosing Unit. NCI Thesaurus. Code C69124.

A dosing unit equal to the amount of active ing redient(s) contained in a gum. 